\title{
Development and performance evaluation of four row self propelled paddy transplanter
}

\section{P.B. GAIKWAD, P.U. SHAHARE, S.V. PATHAK AND V.V. AWARE}

Received : 20.08.2014; Revised : 03.02.2015; Accepted : 17.02.2015

See end of the Paper for authors' affiliation

Correspondence to :

P.B. GAIKWAD

Department of Farm Machinery and Power, College of Agricultural Engineering and Technology, Dr. Balasaheb Sawant Konkan Krishi Vidyapeeth, Dapoli, RATNAGIRI (M.S.) INDIA Email : pravin.bg1807@gmail.com
- ABSTRACT : Rice is generally grown by transplanting seedlings in flooded field conditions or direct sowing depending upon the availability of water. Considering the need of Konkan region of Maharashtra, four row self propelled paddy transplanter was developed. The developed four row self propelled paddy transplanter consists of main frame, engine, gear box, transplanting mechanism, tray movement mechanism and drive system. The commercially available Honda-GK-200 petrol engine $(3.5 \mathrm{hp})$ was selected as a prime mover. Laboratory test results showed that transplanting mechanism and feeding mechanism functions properly. During field trial the results reveal that hill spacing was $12 \mathrm{~cm}$, the planting depth was observed to be $3 \mathrm{~cm}$. The seedlings per hill and missing hills $/ \mathrm{m}^{2}$ were observed to be 3.66 and 4.33 , respectively. The total number hills $/ \mathrm{m}^{2}$ area was obtained as 30 . Fuel consumption for the newly developed transplanter was $1.9 \mathrm{l} / \mathrm{h}$. The field efficiency of the transplanter was 80.47 per cent. The field capacity of the transplanter was $0.14 \mathrm{ha} / \mathrm{h}$.

- KEY WORDS : Paddy transplanter, Mat nursery, Puddled field, Field performance

- HOW TO CITE THIS PAPER : Gaikwad, P.B., Shahare, P.U., Pathak, S.V. and Aware, V.V. (2015). Development and performance evaluation of four row self propelled paddy transplanter. Internat. J. Agric. Engg., 8(1) : 9-14. 